\title{
Physiological roles of connexins in labour and lactation
}

\author{
Gerald M Kidder and Elke Winterhager ${ }^{1}$ \\ Department of Physiology and Pharmacology, Schulich School of Medicine and Dentistry, The University of \\ Western Ontario, London, Ontario N6A 5C1, Canada and ${ }^{1}$ Institute of Molecular Biology, University of \\ Duisburg-Essen, University Clinics, 45211 Essen, Germany
}

Correspondence should be addressed to GM Kidder; Email: gmk@uwo.ca

\begin{abstract}
The connexin family of proteins are best known as oligomerizing to form intercellular membrane channels (gap junctions) that metabolically and ionically couple cells to allow for coordinated cellular function. Nowhere in the body is this role better illustrated than in the uterine smooth muscle during parturition, where gap junctions conduct the contraction wave throughout the tissue to deliver the baby. Parturition is followed by the onset of lactation with connexins contributing to both the dramatic reorganization of mammary gland tissue leading up to lactation and the smooth muscle contraction of the myoepithelial cells which extrudes the milk. This review summarizes what is known about the expression and roles of individual connexin family members in the uterus during labour and in the mammary glands during development and lactation. Connexin loss or malfunction in mammary glands and the uterus can have serious implications for the health of both the mother and the newborn baby.

Reproduction (2015) 150 R129-R136
\end{abstract}

\section{Introduction}

Gap junction connexins comprise a family of 21 genes and cognate proteins in humans. Their best known function is to guarantee direct communication properties between adjacent cells. Connexins are integral membrane proteins with $\mathrm{N}$ - and C-terminal cytoplasmic domains linked by four transmembrane domains, an intracellular loop, and two extracellular loops. The different connexins vary greatly in size mostly due to the length of the $\mathrm{C}$-terminal segment and the proteins are named with respect to their relative molecular masses: connexin43 (CX43), for example, is a $\sim 43 \mathrm{kDa}$ protein. Individual connexins oligomerize to form hexameric structures called connexons or hemichannels in which a central core forms a hydrophilic channel. When inserted into the plasma membrane of a cell, connexons can stand alone or can dock end-to-end with connexons in opposing cells to form intercellular channels that gather into tightly packed arrays known as gap junctions (see Laird (2010) for a comprehensive review of connexin biology). Gap junction channels allow direct sharing of inorganic ions such as $\mathrm{Ca}^{2+}$ as well as small organic metabolites and signalling molecules, including CAMP, cGMP and $\mathrm{IP}_{3}$, between cells without the need for passage through the extracellular space, a phenomenon known as gap junctional intercellular communication (G)IC; Söhl \& Willecke 2003, Harris 2007, Yeager \& Harris 2007). Many cells express multiple connexins, a situation that enables them to form heteromeric connexons (by co-oligomerization) or heterotypic intercellular channels (by docking of connexons of different connexin composition) (Meşe et al. 2007, Koval et al. 2014). These variations in connexin composition result in changes in channel properties including ionic conductance and sensitivity to regulation by $\mathrm{pH}$, transjunctional voltage and phosphorylation (Meşe et al. 2007, Harris \& Contreras 2014). Moreover, a plethora of studies has demonstrated that connexin expression can be modulated at different post-transcriptional steps, although regulation of connexin gene transcription is accepted as an important mechanism in controlling the temporal pattern and amount of connexin protein needed for GJIC. Agents such as steroid hormones and cytokines are well known to upregulate cell-type nonspecific or specific transcription factors required for connexin gene transcription in different organs (for review, see Oyamada et al. (2013)). Regulation of the different connexins plays a significant role in embryogenesis, cell proliferation, apoptosis, migration and differentiation (Haass et al. 2004, Levin 2007, Aasen 2014, Carette et al. 2014). Not surprisingly, altered connexin expression and/or function have been shown to contribute to several diseases and carcinogenesis (Dobrowolski \& Willecke 2009, Laird 2010, Naus \& Laird 2010, Defamie et al. 2014). In particular, connexins are required for several female reproductive functions associated with early stages of pregnancy, which has been reviewed recently (Winterhager \& Kidder 2015). 
Using transgenic mice models, germline deletion of the gene encoding CX43 resulted in oocyte deficiency and impaired follicle growth; cell-specific deletion from growing oocytes reduced embryo implantation competence; and deletion of the gene encoding CX37, which forms gap junctions connecting oocytes with granulosa cells, caused arrest of oocyte development. In the uterine stroma, CX43 regulates decidualization and vascularization in mice as well as in humans. Moreover, the appropriate development and function of a mouse or human placenta is governed by several connexins (Winterhager \& Kidder 2015).

In several contractile tissues such as the heart, the smooth muscle layers of the vasculature and the myometrium, gap junctions are essential for the propagation of electrical signals via direct transfer of ions between cells. In the heart, for example, connexins are a crucial determinant of conductivity in the myocardium and, consequently, impairment of GJIC is associated with cardiac pathologies (for a review, see Lambiase \& Tinker (2014)). In the vasculature, the contraction wave must be propagated efficiently from cell to cell to control vascular tone (reviewed by Johnstone et al. (2009)). In the pregnant uterus, GIIC allows for coordinated contraction of the myometrium during labour (reviewed by Mendelson (2009)). This review focuses on the roles played by individual connexins in the myometrium and the mammary glands, pointing out possible implications of connexin dysfunction for the health of pregnant women and newborns.

\section{Connexin involvement in labour}

Together with the oxytocin receptor, the prostaglandin receptor and cyclooxygenase 2 (COX2), CX43 belongs to the so called myometrial contraction-associated proteins (CAP) or uterine activation proteins (UAP) (Cook et al. 2003), which are able to induce contractility and promote labour (reviewed by Mendelson (2009)). CX43 has been shown to be the dominant connexin in gap junctions connecting rodent and human myometrial cells as well as in cultured myometrial cells (Hendrix et al. 1992; Tabb et al. 1992, Miyoshi et al. 1998). Experiments with isolated human myometrial cells have provided direct evidence for functional ionic coupling via CX43 gap junctions by measuring junctional conductance, dye spreading and intercellular calcium waves (Sakai et al. 1992, Miyoshi et al. 1998, Young et al. 2002). In rodent pregnancy, high levels of progesterone acting via its receptors (PRA and PRB) in the myometrium suppress CX43 transcript and protein expression and thereby limit myometrial contractility in order to maintain pregnancy and avoid preterm labour (Ou et al. 1997, Shynlova et al. 2009). Interaction with the transcriptional co-repressor p54NRB is reported to stabilize the progesterone receptor-mediated CX43 suppression (Dong et al. 2009), keeping the myometrium quiescent. Previous investigations had shown that not only progesterone but, in addition, defined levels of hCG directly suppress CX43 synthesis and thus represent another hormonal factor that downregulates gap junctional communication to maintain myometrial cell quiescence (Ambrus \& Rao 1994).

As pregnancy proceeds, molecular changes in the myometrium driven by both ovarian hormones and mechanical stretch prepare the uterus for the onset of labour by inducing CAP/UAP genes (reviewed by Shynlova et al. (2009)). Among these changes is the dramatic upregulation of CX43 and, as a result, a large number of gap junctions is induced to establish ionic coupling among the myometrial smooth muscle cells, providing for synchronization of their contractions (Garfield et al. 1988). The upregulation of CX43 expression is caused by progesterone withdrawal and an increase in estrogen (Lye et al. 1993). It has been shown that the rodent Gja1 gene encoding CX43 is under the control of estrogen, and its activation is probably mediated by promoter sequences resembling half-palindromic estrogen response elements (Petrocelli \& Lye 1993). It has been further reported that the expression levels of the AP1 family transcription factors $\mathrm{c}$-jun and c-fos are strongly increased in the myometrium before labour and are regulated by both mechanical and hormonal stimuli. The dimers drive promoter activity of the Gja1 gene by binding to its distal AP1 binding site (Piersanti \& Lye 1995, Mitchell \& Lye 2005). Thus, AP1 regulation seems to play a crucial role in CX43 induction in the pregnant myometrium at term. However, other findings suggest that, in the human myometrium, the AP1 transcription factor, which is upregulated by estrogen and protein kinase $C$ (PKC), interacts directly through an AP1 site of the GJA1 promoter sequence and is independent from the estrogen receptor (Geimonen et al. 1996, 1998). Although in many species, the drop in progesterone combined with a dominance of estrogen action appears to be the crucial factor in the initiation of parturition, this may not be true for the human because plasma progesterone levels do not decline before or during labour and PRA and PRB remain elevated in the myometrium throughout pregnancy (Challis et al. 2000). Several studies attempt to unravel the molecular mechanism by which progesterone and its receptors contribute to the upregulation of the uterine activation proteins in humans. Condon et al. (2003) proposed a functional progesterone inactivation at labour by impairment of the transcriptional activity of the progesterone-progesterone receptor (PR) complex resulting in a decrease in PR-responsive genes. Xie et al. (2012) described that PR interacts with the GJA1 promoter through AP1 transcription factors in the presence of progesterone, and suppression of CX43 transcription during pregnancy is mediated via the recruitment of the PR co-regulator, polypyrimidine tract binding proteinassociated splicing factor (PSF), and of the yeast switch 
independent three homolog A/histone deacetylase co-repressor complex. Because of the decrease in PSF at term, the de-repressed PR transcriptional activity might abrogate the suppression of CAP genes for labour, mimicking a withdrawal of progesterone action.

The role of CX43 in labour is influenced by other signalling pathways, in addition to steroid hormones. Tan et al. (2012) suggested that the dominant progesterone receptor $\mathrm{B}(\mathrm{PRB})$ maintains myometrial quiescence, but at parturition, the rise in PRA expression promotes labour by stimulating proinflammatory gene expression in response to progesterone. It has been shown that upregulation of prostaglandin signalling induces the expression of labour-associated proteins, including CX43. In mice, PGF2 $\alpha$ could induce preterm labour by increasing the uterine activation proteins CX43, oxytocin receptor, prostaglandin receptor and PTGS-2 (Cook et al. 2000, 2003). In human myometrial cells, an increase of PGF $2 \alpha$ acts directly on CX43 expression levels as evidenced by its inhibition by indomethacin treatment. The stimulatory effect of PGF $2 \alpha$ on the uterine activation proteins is enhanced in combination with IL1ß (Xu et al. 2013). Although PGF2 $\alpha$ dose-dependently increased the uterine activation proteins, including CX43 (Xu et al. 2013), the most highly expressed prostaglandin in human myometrium is PGI2 (Omini et al. 1979), which is normally known as a smooth muscle relaxant (Taggart et al. 2008). In the pregnant human myometrium at term, however, PGI2 mediates upregulation of CX43 and contractile proteins such as SM-MHC and $\alpha$-SMA via activating PKA in human myometrial cells in vitro, resulting in an enhanced contractile response to oxytocin (Fetalvero et al. 2008).

Little is known about the posttranscriptional regulation of connexin expression in myometrial cells that may occur via modulation of CX43 mRNA stability, regulation of its translation and/or modulation of CX43 turnover (reviewed by Klotz (2012)). To date, microRNAs of the miRNA-200 family, the zinc finger E-box binding homeobox proteins ZEB1 and ZEB2, have been identified as being upregulated by progesterone and its receptor in the pregnant uterus. Both miRNAs act as transcriptional repressors for the oxytocin and CX43 genes, blocking the transition into the contractile phenotype (Renthal et al. 2010, Zakar \& Mesiano 2011). Moreover, in rat liver epithelial cellsHuRn, an RNA binding protein, stabilizes CX43 expression such that silencing of HuRn lowered the level of CX43 mRNA and protein and decreased CX43 mRNA half-life (Ale-Agha et al. 2009). In addition, HuR silencing reduced $\beta$-catenin, which is known to be required to maintain $\mathrm{CX} 43$ at the plasma membrane (Ale-Agha et al. 2009). Despite this evidence, it is not known if HuR contributes to the regulation of CX43 in the pregnant myometrium. Altogether, a number of mechanisms undoubtedly contribute to the onset of connexin induction in the human myometrium at term, and a precise mechanism whereby transcription of the gene encoding CX43 is regulated in this context remains elusive.

Other connexins including CX26 (in rat: Ou et al. (1997)), CX40 (in mice and humans: Kilarski et al. (2001) and Döring et al. (2006) respectively) and CX45 (in humans: Kilarski et al. $(1998,2001))$ have been identified in the myometrium, but it is not known if they form heteromeric or heterotypic gap junction channels with CX43 in this context. Their involvement in human labour has not yet been elucidated. In the mouse model, the genes encoding connexins 26, 40 and 45 have been ablated, but the results have not been informative as to their potential importance for labour: CX26 and CX45 knockout mice die in utero (Gabriel et al. 1998, Krüger et al. 2000, Kumai et al. 2000) whereas CX40 knockout females were reported to be fertile without any reproductive problems being noted (Kirchhoff et al. 1998). See Table 1 for a summary of mouse connexin mutants affecting labour and/or lactation.

Two independent studies in the mouse have supported that GJIC among the myometrial smooth muscle cells is required for coordination of the uterine contractions that expel the fetus during parturition. Döring et al. (2006) used the inducible Cre-LoxP system to generate female mice in which the gene encoding CX43 was ablated in the myometrial smooth muscle cells 1 week before the females were mated. Not surprisingly, the knockout markedly decreased GJIC among the smooth muscle cells, but the expression of several selected myometrial CAP genes was not affected, indicating that, despite being uncoupled, the cells' ability to contract remained intact. The result of this targeted knockout was that the females exhibited a delay in parturition in comparison with their unaffected counterparts, with less than onefifth of the knockout dams being able to deliver their pups within the normal temporal window. The researchers failed to find any hormonal differences that could explain the delayed parturition, hence it was attributed to reduced ionic coupling that impaired myometrial contraction. A similar effect on parturition was seen in the second study (Tong et al. 2009) in which myometrial function was analysed during parturition in female mice expressing a dominant mutant form of CX43 $\left(\mathrm{CX} 43^{\mathrm{G} 60 \mathrm{~S}}\right)$, which reduced the amount of the connexin in cell membranes and the strength of GIIC by $\sim 85 \%$ measured electrophysiologically. Myometrial contraction strength in response to oxytocin was correspondingly impaired, resulting in delayed parturition along with, in some cases, failure of some pups or placentas to be expelled. Collectively, these two studies make it clear that CX43 is essential for parturition in the mouse. Given that the two mutations severely reduced GJIC between the myometrial cells by different means (gene knockout vs mutation that impairs the ability of CX43 to assemble into gap junctions), it is most likely that the role of CX43 in parturition is to provide for ionic coupling of the myometrial cells to coordinate contraction. 
Table 1 Connexin importance for labour and lactation revealed in mutant mice.

\begin{tabular}{|c|c|c|c|c|}
\hline Connexin & Genetic alteration & Effect on labour & Effect on lactation & References \\
\hline \multirow[t]{2}{*}{$\mathrm{CX} 26$} & $\begin{array}{l}\text { Mammary ductal } \\
\text { epithelium-specific knockout }\end{array}$ & None reported & $\begin{array}{l}\text { Impaired gland development, } \\
\text { impaired lactation }\end{array}$ & Bry et al. (2004) \\
\hline & $\begin{array}{l}\text { Mammary gland-specific } \\
\text { knockdown of lactational } \\
\text { expression surge }\end{array}$ & None reported & $\begin{array}{l}\text { Comparatively normal gland } \\
\text { development and function }\end{array}$ & Stewart et al. (2014) \\
\hline CX30 & Germline knockout & No reproductive impairment & No reproductive impairment & Teubner et al. (2003) \\
\hline CX32 & Germline knockout & None reported & Gland development not affected & Bry et al. (2004) \\
\hline CX40 & Germline knockout & None reported & None reported & Kirchhoff et al. (1998) \\
\hline \multirow[t]{6}{*}{ CX43 } & $\begin{array}{l}\text { Myometrial smooth muscle- } \\
\text { specific knockout }\end{array}$ & Delayed parturition & None reported & Döring et al. (2006) \\
\hline & $\begin{array}{l}\text { Dominant loss-of-function } \\
\text { germline mutation (G60S) }\end{array}$ & $\begin{array}{l}\text { Delayed and incomplete } \\
\text { parturition }\end{array}$ & $\begin{array}{l}\text { Delayed mammary duct } \\
\text { development; impaired } \\
\text { milk ejection }\end{array}$ & $\begin{array}{l}\text { Tong et al. (2009), Plante \& } \\
\text { Laird (2008) and Plante } \\
\text { et al. (2010) }\end{array}$ \\
\hline & $\begin{array}{l}\text { Dominant loss-of-function } \\
\text { germline mutation (I130T) }\end{array}$ & None reported & $\begin{array}{l}\text { Delay in ductal elongation; } \\
\text { glands smaller but milk } \\
\text { ejection unaffected }\end{array}$ & Stewart et al. (2013) \\
\hline & $\begin{array}{l}\text { Heterozygous germline knockin } \\
\quad(\text { CX26 replaced CX43) }\end{array}$ & None reported & $\begin{array}{l}\text { Impairment of lactation due to } \\
\text { gland under-development }\end{array}$ & Winterhager et al. (2007) \\
\hline & $\begin{array}{l}\text { Germline knockin } \\
\quad(\mathrm{CX} 32 \text { replaced CX43) }\end{array}$ & None reported & Impaired milk ejection & Plum et al. (2000) \\
\hline & $\begin{array}{l}\text { Germline knockin } \\
\quad(\text { CX40 replaced CX43) }\end{array}$ & None reported & None reported & Plum et al. (2000) \\
\hline
\end{tabular}

\section{Implicating connexins in birth complications}

There is sufficient evidence that CX43 in the human myometrium serves the same function that has been demonstrated in the mouse. For example, reduced expression of this connexin correlates with prolonged labour (Cluff et al. 2006). Moreover, early onset of CX43 induction or impaired suppression of CX43 expression may be correlated with preterm birth, a leading cause for neonatal morbidity and mortality and thus a major health problem (Blencowe et al. 2012). A decrease in progesterone level and/or a functional progesterone withdrawal are known reasons for the onset of expression of CAP genes, including CX43, at birth (Mendelson 2009). Research with women or using animal models has shown that prolonged administration of progesterone is able to prevent preterm birth (Norman et al. 2011). Progesterone probably acts as an antiinflammatory hormone and prevents prostacyclin activation (Fetalvero et al. 2008). Interfering with prostaglandin synthesis as a therapeutic treatment to arrest myometrial contraction was considered to be a promising approach, but there is little evidence that COX2 inhibitors could prevent preterm labour as shown by a recent Cochrane study (Khanprakob et al. 2012). Recently, Gonzalez et al. (2014) uncovered another mechanism of CX43 induction involving complement C5a activation in human and mouse myometrium; inhibition of $\mathrm{C} 5 \mathrm{a}$ activation by statins can prevent myometrial contractions. The posttranscriptional regulation by ZEB miRNA-200 could serve as another target for therapeutic treatment by creating inhibitors for the signalling cascades controlling this specific miRNA as mentioned by Zakar \& Mesiano (2011) and Klotz (2012). It must be kept in mind, however, that clinical therapies to prevent preterm birth are always accompanied by a risk for fetal development. Nevertheless, a better understanding of the molecular events that regulate the transition from the quiescent pregnant myometrium to the contractile state would improve therapies for preterm labour. In this context, direct functional studies on the regulation of myometrial gap junction channels may suggest new strategies for preventing preterm birth.

\section{Connexin involvement in lactation}

Several connexins have been identified as forming gap junctions in various compartments of the developing and mature mammary glands of rodents and humans (reviewed by Stewart et al. (2015)). The mammary gland is one of several secretory organs that develop from an interaction between epithelial and mesenchymal rudiments; in the mammary gland, this culminates in a series of ducts emanating from milk-producing alveoli. The ducts are surrounded by myoepithelial cells whose contraction in response to the pituitary hormone, oxytocin, drives milk ejection. During pregnancy, duct expansion occurs as the alveolar cells ramp up for postpartum milk production. In both mouse and human, CX43 is expressed in the glandular stroma and luminal cells in addition to forming gap junctions connecting the myoepithelial cells (Fig. 1). CX26 is also prominent in human luminal cells, whereas in mice, CX26, CX30 and CX32 all contribute to gap junctions connecting the luminal epithelial cells (Stewart et al. 2015). Surprisingly, a recent study also identified CX46 in both luminal and myoepithelial cells of the human mammary gland despite its not having been reported in the mouse (Teleki et al. 2014). 

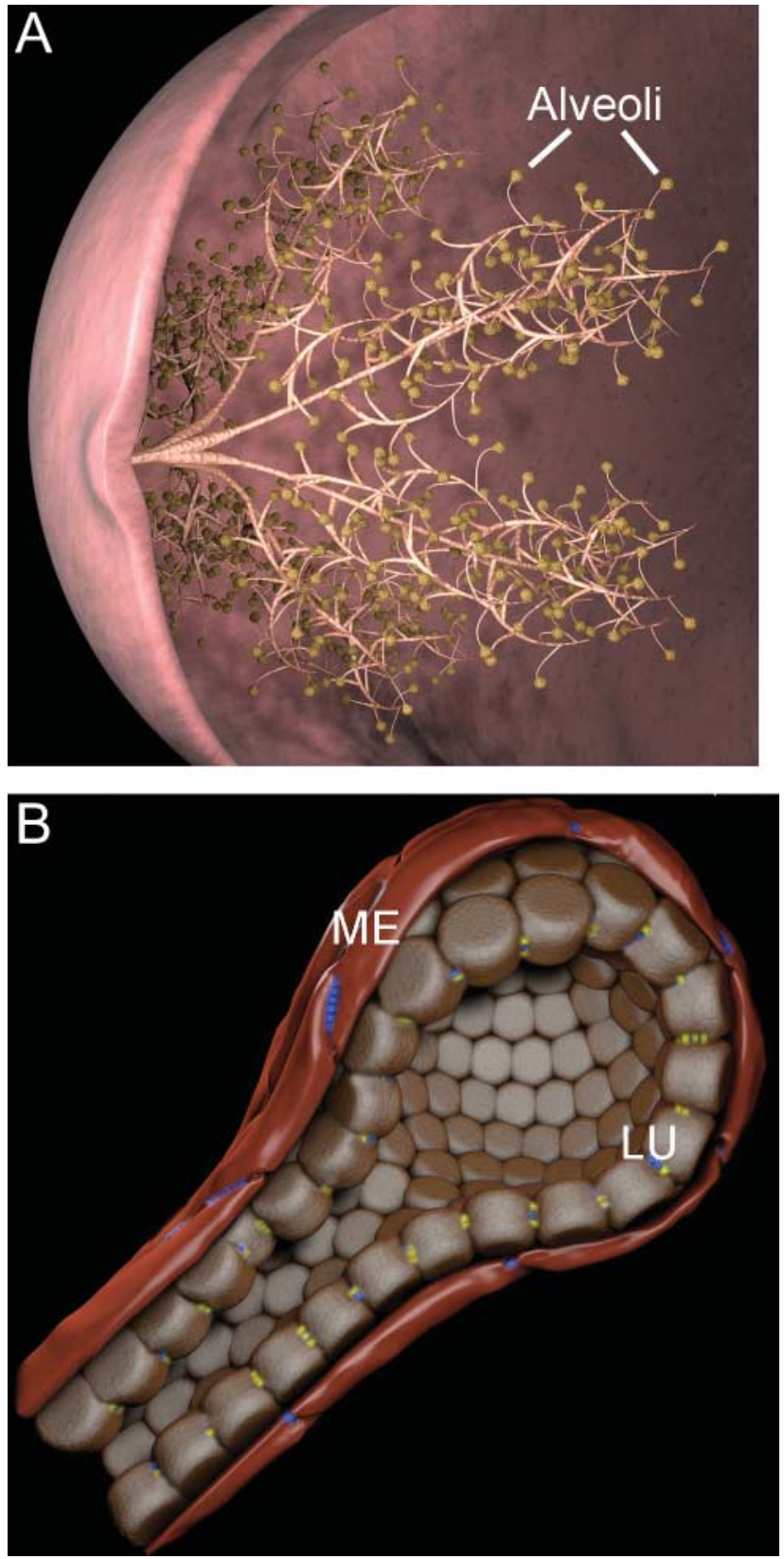

Figure 1 Two connexins are prominent in the human mammary gland. (A) Alveoli are the milk-producing elements of the gland, with the milk being conducted to the nipple via a converging system of ducts.

(B) CX43 gap junctions (blue) couple the contractile myoepithelial cells (ME), whereas CX26 (yellow) predominates in gap junctions coupling the luminal cells (LU) of the alveoli and ducts.

The roles of connexins 26, 30 and 32 in mammary gland development and lactation have been explored through mouse gene knockouts (Table 1). Bry et al. (2004) used a transgene to drive Cre recombinase expression in the ductal epithelium of the mouse mammary glands to effect deletion of the gene encoding CX26 before puberty. This early loss of CX26 abrogated the growth and functional differentiation of the gland, with the consequence that post-parturition lactation was impaired and pup survival reduced, demonstrating an essential role for CX26 in glandular development. In contrast, when CX26 expression was knocked down later during lactation, gland development was essentially normal, as indicated by the production of milk proteins (Stewart et al. 2014). Interestingly, Bry et al. (2004) also reported that mammary gland development was not affected by the germline knockout of the gene encoding CX32. Likewise, Teubner et al. (2003) did not find any obvious reproductive impairment in female mice lacking CX30, although the mammary glands were not specifically examined in that study. The roles of CX43 in mammary gland development and lactation have been explored using the $\mathrm{CX} 43^{\mathrm{G} 60 \mathrm{~S}}$ mutant mouse line (Plante \& Laird 2008, Plante et al. 2010). A temporary delay in postnatal ductal development and a reduction of the gland's size were noted in $\mathrm{CX} 43^{\mathrm{G} 60 \mathrm{~S}}$ expressing females in comparison with their WT littermates. Not surprisingly, considering the presence of this connexin in their myoepithelial gap junctions, oxytocin-stimulated milk ejection from the mutant mammary glands was impaired. In contrast, in mice expressing a less severe loss of function mutant (CX43 $\left.{ }^{1130 \mathrm{~T}}\right)$, the mammary glands were reduced in size but milk ejection was not affected (Stewart et al. 2013).

Given the contrasting roles of the different mammary gland compartments - secretion vs contraction in response to different hormonal stimuli - it is tempting to speculate that the connexins expressed in mammary glands are spatially restricted based on the different properties of the intercellular membrane channels that they form, either singly or, where co-expressed in the same cells, in various connexin combinations (see Locke et al. 2000, 2004). The principle of functional uniqueness of CX43 in the mouse mammary gland was tested by Plum et al. (2000), who replaced the genomic CX43 coding sequence with that encoding either CX32 or $\mathrm{CX} 40$ (termed $\mathrm{CX} 43^{\mathrm{KI} 32}$ and $\mathrm{CX} 43^{\mathrm{K} / 40}$ mice respectively). Whereas CX40 was able to replace CX43 without impairing mammary gland function, CX32 was not, resulting in restricted postnatal growth and diminished survival of $\mathrm{CX} 43^{\mathrm{K} 132}$ pups, even those born of mothers heterozygous for the gene replacement. As expected, the CX $43^{\mathrm{K} 132}$ pups could be rescued by cross-fostering to WT mothers. Histological analysis indicated that lactation failure was at the core of the $\mathrm{CX} 43^{\mathrm{K} 132}$ mutant phenotype, due not to impaired milk production but rather to impaired myoepithelial contraction. When the same analysis was applied to mice in which the CX43 coding sequence had been replaced by that of CX26 (CX43 ${ }^{\mathrm{KI} 26}$ mice), the result was again an impairment of lactation, but in this case it appeared to be due to underdevelopment of the alveoli and ducts (Winterhager et al. 2007). Collectively, these gene replacement experiments point to unique (i.e., nonredundant) roles 
for CX43 in different aspects of mammary gland development and function.

\section{Conclusion and future directions}

It is clear from the research summarized above that several connexins play important roles in parturition and lactation in the mouse and, based on similarities in expression domains, likely also in the human. This implies that perturbations of connexin function could pose risks for pregnant women and their newborn babies. Prolonged labour, for example, would be a likely consequence of any reduction in the level of expression or the function of CX43 in the myometrium, conditions that would reduce the strength of contractions and possibly necessitate delivery by Cesarean section. On the other hand, promoting the expression of CX43 in the quiescent myometrium in pregnancy contributes to preterm birth. Similarly, a delay in mammary gland maturation during late pregnancy would be a possible consequence of reduced CX26 expression/function, whereas CX43 deficiency would be expected to blunt the effect of oxytocin in inducing postnatal milk extrusion. The seriousness of this latter effect could be compounded if, as in the mouse (Winterhager et al. 2013), a reduced level of CX43 in the decidual tissue results in intrauterine growth restriction, a condition that increases the importance of breastfeeding (Bozzetti et al. 2013, Tudehope et al. 2013). Such scenarios are not merely hypothetical, given that numerous human diseases and disabilities have been linked with mutations in connexin genes (Dobrowolski \& Willecke 2009), including those encoding connexins mentioned in this review.

Going forward, more research with mutant mice will be needed to refine our understanding of connexin involvement in labour and lactation. For example, there is still much to be learned about the intercellular signalling pathways and connexin modifications involved in the endocrine-regulated acquisition of myometrial contractility that presages labour. Phosphorylation of CX43 undoubtedly plays a role in that process, given the importance of phosphorylation in regulating gap junction assembly and turnover (Solan \& Lampe 2014) and the fact that CX43 phosphorylation is known to be disrupted in the myometrium of CX43 ${ }^{\mathrm{G} 60 \mathrm{~S}}$ mutant mice with impaired parturition (Tong et al. 2009). We also need to know why CX43 is critical for mammary duct development, in addition to its well-understood role in conducting the contraction waves that effect milk extrusion. For each of the several connexins known to be involved in parturition or lactation, its critical role whether as undocked hemichannels in the plasma membrane, as intercellular gap junction channels, or as performing some intracellular function - must be determined. Above all, it will be important to track pregnancies in women carrying disease-causing connexin gene mutations (Gerido \& White 2004, Richard 2005, Laird 2008, Paznekas et al. 2009) in order to identify possible adverse effects on labour and/ or lactation.

\section{Declaration of Interest}

The authors declare that there is no conflict of interest that could be perceived as prejudicing the impartiality of this review.

\section{Funding}

E Winterhager acknowledges funding from the Deutsche Forschungsgemeinschaft and G M Kidder acknowledges funding from the Canadian Institutes of Health Research.

\section{Acknowledgements}

The authors are grateful to Dale Laird and Michael Stewart for their comments on an early draft of the manuscript and to Jamie Simek for assistance with preparing Fig. 1.

\section{References}

Aasen T 2014 Connexins: junctional and non-junctional modulators of proliferation. Cell and Tissue Research 360 685-699. (doi:10.1007/ s00441-014-2078-3)

Ale-Agha N, Galban S, Sobieroy C, Abdelmohsen K, Gorospe M, Sies H \& Klotz LO 2009 HuR regulates gap junctional intercellular communication by controlling $\beta$-catenin levels and adherens junction integrity. Hepatology 50 1567-1576. (doi:10.1002/hep.23146)

Ambrus G \& Rao CV 1994 Novel regulation of pregnant human myometrial smooth muscle cell gap junctions by human chorionic gonadotropin. Endocrinology 135 2772-2779.

Blencowe H, Cousens S, Oestergaard MZ, Chou D, Moller AB, Narwal R, Adler A, Vera Garcia C, Rohde S, Say L et al. 2012 National, regional, and worldwide estimates of pretermbirth rates in the year 2010 with time trends since 1990 for selected countries: a systematic analysis and implications. Lancet $379 \quad 2162-2172$. (doi:10.1016/S0140-6736 (12)60820-4)

Bozzetti V, Tagliabue PE, Visser GH, van Bel F \& Gazzolo D 2013 Feeding issues in IUGR preterm infants. Early Human Development 89 (Suppl 2) S21-S23. (doi:10.1016/j.earlhumdev.2013.07.006)

Bry C, Maass K, Miyoshi K, Willecke K, Ott T, Robinson GW \& Hennighausen L 2004 Loss of connexin 26 in mammary epithelium during early but not during late pregnancy results in unscheduled apoptosis and impaired development. Developmental Biology 267 418-429. (doi:10.1016/j.ydbio.2003.11.022)

Carette D, Gilleron J, Chevallier D, Segretain D \& Pointis G 2014 Connexin a check-point component of cell apoptosis in normal and physiopathological conditions. Biochimie 101 1-9. (doi:10.1016/ j.biochi.2013.11.015)

Challis JR, Matthews SG, Gibb W \& Lye SJ 2000 Endocrine and paracrine regulation of birth at term and preterm. Endocrine Reviews 21 514-550.

Cluff AH, Byström B, Klimaviciute A, Dahlqvist C, Cebers G, Malmström A \& Ekman-Ordeberg G 2006 Prolonged labour associated with lower expression of syndecan 3 and connexin 43 in human uterine tissue. Reproductive Biology and Endocrinology 4 24. (doi:10.1186/14777827-4-24)

Condon JC, Jeyasuria P, Faust JM, Wilson JW \& Mendelson CR 2003 A decline in the levels of progesterone receptor coactivators in the pregnant uterus at term may antagonize progesterone receptor function and contribute to the initiation of parturition. PNAS 100 9518-9523. (doi:10.1073/pnas.1633616100) 
Cook JL, Zaragoza DB, Sung DH \& Olson DM 2000 Expression of myometrial activation and stimulation genes in a mouse model of preterm labor: myometrial activation, stimulation, and preterm labor. Endocrinology 14 1718-1728. (doi:10.1210/endo.141.5.7474)

Cook JL, Shallow MC, Zaragoza DB, Anderson KI \& Olson DM 2003 Mouse placental prostaglandins are associated with uterine activation and the timing of birth. Biology of Reproduction 68 579-587. (doi:10.1095/ biolreprod.102.008789)

Defamie N, Chepied A \& Mesnil M 2014 Connexins, gap junctions and tissue invasion. FEBS Letter 588 1331-1338. (doi:10.1016/j.febslet.2014. 01.012)

Dobrowolski R \& Willecke K 2009 Connexin-caused genetic diseases and corresponding mouse models. Antioxidants \& Redox Signaling 11 283-295. (doi:10.1089/ars.2008.2128)

Dong X, Yu C, Shynlova O, Challis JR, Rennie PS \& Lye SJ 2009 p54nrb is a transcriptional corepressor of the progesterone receptor that modulates transcription of the labor-associated gene, connexin 43 (Gja1). Molecular Endocrinology 23 1147-1160. (doi:10.1210/me.2008-0357)

Döring B, Shynlova O, Tsui P, Eckardt D, Janssen-Bienhold U, Hofmann F, Feil S, Feil R, Lye SJ \& Willecke K 2006 Ablation of connexin43 in uterine smooth muscle cells of the mouse causes delayed parturition. Journal of Cell Science 119 1715-1722.

Fetalvero KM, Zhang P, Shyu M, Young BT, Hwa J, Young RC \& Martin KA 2008 Prostacyclin primes pregnant human myometrium for an enhanced contractile response in parturition. Journal of Clinical Investigation 118 3966-3979.

Gabriel H-D, Jung D, Bützler C, Temme A, Traub O, Winterhager E \& Willecke K 1998 Transplacental uptake of glucose is decreased in embryonic lethal connexin 26-deficient mice. Journal of Cell Biology 140 1453-1461. (doi:10.1083/jcb.140.6.1453)

Garfield RE, Blennerhassett MG \& Miller SM 1988 Control of myometrial contractility: role and regulation of gap junctions. Oxford Reviews of Reproductive Biology 10 436-490.

Geimonen E, Jiang W, Ali M, Fishman GI, Garfield RE \& Anderson J 1996 Activation of protein kinase $\mathrm{C}$ in human uterine smooth muscle induces connexin-43 gene transcription through an AP-1 site in the promoter sequence. Journal of Biological Chemistry 271 23667-23674. (doi:10. 1074/jbc.271.39.23667)

Geimonen E, Boylston E, Royek A \& Andersen J 1998 Elevated connexin-43 expression in term human myometrium correlates with elevated c-Jun expression and is independent of myometrial estrogen receptors. Journal of Clinical Endocrinology and Metabolism 83 1177-1185.

Gerido DA \& White TW 2004 Connexin disorders of the ear, skin, and lens. Biochimica et Biophysica Acta 1662 159-170. (doi:10.1016/j.bbamem. 2003.10.017)

Gonzalez JM, Pedroni SM \& Girardi G 2014 Statins prevent cervical remodeling, myometrial contractions and preterm labor through a mechanism that involves hemoxygenase- 1 and complement inhibition. Molecular Human Reproduction 20 579-589. (doi:10.1093/molehr/ gau019)

Haass NK, Smalley KS \& Herlyn M 2004 The role of altered cell-cell communication in melanoma progression. Journal of Molecular Histology 35 309-318. (doi:10.1023/B:HIJO.0000032362.35354.bb)

Harris AL 2007 Connexin channel permeability to cytoplasmic molecules. Progress in Biophysics and Molecular Biology 94 120-143. (doi:10. 1016/j.pbiomolbio.2007.03.011)

Harris AL \& Contreras JE 2014 Motifs in the permeation pathway of connexin channels mediate voltage and $\mathrm{Ca}(2+)$ sensing. Frontiers in Physiology 5 113-126. (doi:10.3389/fphys.2014.00113)

Hendrix EM, Mao SJ, Everson W \& Larsen WJ 1992 Myometrial connexin 43 trafficking and gap junction assembly at term and in preterm labor. Molecular Reproduction and Development 33 27-38. (doi:10.1002/mrd. 1080330105)

Johnstone S, Isakson B \& Locke D 2009 Biological and biophysical properties of vascular connexin channels. International Review of Cell and Molecular Biology 278 69-118.

Khanprakob T, Laopaiboon $M$, Lumbiganon $P$ \& Sangkomkamhang US 2012 Cyclo-oxygenase (COX) inhibitors for preventing preterm labour. Cochrane Database of Systematic Reviews 17 CD007748.

Kilarski WM, Dupont E, Coppen S, Yeh HI, Vozzi C, Gourdie RG, Rezapour M, Ulmsten U, Roomans GM \& Severs NJ 1998 Identification of two further gap-junctional proteins, connexin 40 and connexin 45, in human myometrial smooth muscle cells at term. European Journal of Cell Biology 75 1-8. (doi:10.1016/S0171-9335 (98)80040-X)

Kilarski WM, Rothery S, Roomans GM, Ulmsten U, Rezapour M, Stevenson S, Coppen SR, Dupont E \& Severs NJ 2001 Multiple connexins localized to individual gap-junctional plaques in human myometrial smooth muscle. Microscopy Research and Technique 54 114-122. (doi:10.1002/jemt.1126)

Kirchhoff S, Nelles E, Hagendorff A, Krüger O, Traub O \& Willecke K 1998 Reduced cardiac conduction velocity and predisposition to arrhythmias in connexin 40-deficient mice. Current Biology 8 299-302. (doi:10. 1016/S0960-9822(98)70114-9)

Klotz LO 2012 Posttranscriptional regulation of connexin-43 expression. Archives of Biochemistry and Biophysics 524 23-29. (doi:10.1016/j.abb. 2012.03.012)

Koval M, Molina SA \& Burt JM 2014 Mix and match: investigating heteromeric and heterotypic gap junction channels in model systems and native tissues. FEBS Letter 588 1193-1204. (doi:10.1016/j.febslet.2014. 02.025)

Krüger O, Plum A, Kim J-S, Winterhager E, Maxeiner S, Hallas G, Kirchhoff S, Traub O, Lamers WH \& Willecke K 2000 Defective vascular development in connexin 45-deficient mice. Development 127 4179-4193.

Kumai M, Nishii K, Nakamura K, Takeda N, Suzuki M \& Shibata Y 2000 Loss of connexin 45 causes a cusion defect in early cardiogenesis. Development 127 3501-3512.

Laird DW 2008 Closing the gap on autosomal dominant connexin-26 and connexin-43 mutants linked to human disease. Journal of Biological Chemistry 283 2997-3001. (doi:10.1074/jbc.R700041200)

Laird DW 2010 The gap junction proteome and its relationship to disease. Trends in Cell Biology 20 92-101. (doi:10.1016/j.tcb.2009.11.001)

Lambiase PD \& Tinker A 2014 Connexins in the heart. Cell and Tissue Research 360 675-684. (doi:10.1007/s00441-014-2020-8)

Levin M 2007 Gap junctional communication in morphogenesis. Progress in Biophysics and Molecular Biology 94 186-206. (doi:10.1016/j. pbiomolbio.2007.03.005)

Locke D, Perusinghe N, Newman T, Jayatilake H, Evans WH \& Monaghan P 2000 Developmental expression and assembly of connexins into homomeric and heteromeric gap junction hemichannels in the mouse mammary gland. Journal of Cellular Physiology 183 228-237. (doi:10. 1002/(SICl) 1097-4652(200005)183:2 <228::AID-JCP9>3.0.CO;2-Y)

Locke D, Stein T, Davies C, Morris J, Harris AL, Evans WH, Monaghan P \& Gusterson B 2004 Altered permeability and modulatory character of connexin channels during mammary gland development. Experimental Cell Research 298 643-660. (doi:10.1016/j.yexcr.2004.05.003)

Lye SJ, Nicholson BJ, Mascrenhas L, MacKenzie L \& Petrocelli T 1993 Increased expression of connexin-43 in the rat myometrium during labor is associated with an increase in plasma estrogen:progesterone ratio. Endocrinology 132 2380-2386.

Mendelson CR 2009 Minireview: fetal-maternal hormonal signaling in pregnancy and labor. Molecular Endocrinology 23 947-954. (doi:10. 1210/me.2009-0016)

Meşe G, Richard G \& White TW 2007 Gap junctions: basic structure and function. Journal of Investigative Dermatology 127 2516-2524. (doi:10. 1038/sj.jid.5700770)

Mitchell JA \& Lye SJ 2005 Differential activation of the connexin 43 promoter by dimers of activator protein-1 transcription factors in myometrial cells. Endocrinology 146 2048-2054. (doi:10.1210/en. 2004-1066)

Miyoshi H, Boyle MB, MacKay LB \& Garfield RE 1998 Gap junction currents in cultured muscle cells from human myometrium. American Journal of Obstetrics and Gynecology 178 588-593. (doi:10.1016/ S0002-9378(98)70443-0)

Naus CC \& Laird DW 2010 Implications and challenges of connexin connections to cancer. Nature Reviews. Cancer 106 435-441. (doi:10. 1038/nrc2841)

Norman JE, Yuan M, Anderson L, Howie F, Harold G, Young A, Jordan F, McInnes I \& Harnett MM 2011 Effect of prolonged in vivo administration of progesterone in pregnancy on myometrial gene expression, peripheral blood leukocyte activation, and circulating steroid hormone levels. Reproductive Sciences 18 435-446. (doi:10.1177/1933719110395404) 
Omini C, Folco GC, Pasargiklian R, Fano M \& Berti F 1979 Prostacyclin (PGI2) in pregnant human uterus. Prostaglandins 17 113-120. (doi:10. 1016/0090-6980(79)90082-0)

Ou CW, Orsino A \& Lye SJ 1997 Expression of connexin-43 and connexin26 in the rat myometrium during pregnancy and labor is differentially regulated by mechanical and hormonal signals. Endocrinology 138 5398-5407.

Oyamada M, Takebe K \& Oyamada Y 2013 Regulation of connexin expression by transcription factors and epigenetic mechanisms. Biochimica et Biophysica Acta 1828 118-233. (doi:10.1016/j.bbamem.2011. 12.031)

Paznekas WA, Karczeski B, Vermeer S, Lowry RB, Delatycki M, Laurence F, Koivisto PA, Van Maldergem L, Boyadjiev SA, Bodurtha JN et al. 2009 GJA1 mutations, variants, and connexin 43 dysfunction as it relates to the oculodentodigital dysplasia phenotype. Human Mutation 30 724-733. (doi:10.1002/humu.20958)

Petrocelli T \& Lye SJ 1993 Regulation of transcripts encoding the myometrial gap junction protein, connexin-43, by estrogen and progesterone. Endocrinology 133 284-290.

Piersanti M \& Lye SJ 1995 Increase in messenger ribonucleic acid encoding the myometrial gap junction protein, connexin-43, requires protein synthesis and is associated with increased expression of the activator protein-1, c-fos. Endocrinology 136 3571-3578.

Plante I \& Laird DW 2008 Decreased levels of connexin43 result in impaired development of the mammary gland in a mouse model of oculodentodigital dysplasia. Developmental Biology 318 312-322. (doi:10.1016/j.ydbio.2008.03.033)

Plante I, Wallis A, Shao Q \& Laird DW 2010 Milk secretion and ejection are impaired in the mammary gland of mice harboring a Cx43 mutant while expression and localization of tight and adherens junction proteins remain unchanged. Biology of Reproduction 82 837-847. (doi:10.1095/ biolreprod.109.081406)

Plum A, Hallas G, Magin T, Dombrowski F, Hagendorff A, Schumacher B, Wolpert C, Kim J-S, Lamers WH, Evert M et al. 2000 Unique and shared functions of different connexins in mice. Current Biology 10 1083-1091. (doi:10.1016/S0960-9822(00)00690-4)

Renthal NE, Chen CC, Williams KC, Gerard RD, Prange-Kiel J \& Mendelson CR 2010 miR-200 family and targets, ZEB1 and ZEB2, modulate uterine quiescence and contractility during pregnancy and labor. PNAS 107 20828-20833. (doi:10.1073/pnas.1008301107)

Richard G 2005 Connexin disorders of the skin. Clinics in Dermatology 23 23-32. (doi:10.1016/j.clindermatol.2004.09.010)

Sakai N, Tabb T \& Garfield RE 1992 Studies of connexin 43 and cell-to-cell coupling in cultured human uterine smooth muscle. American Journal of Obstetrics and Gynecology 167 1267-1277. (doi:10.1016/ S0002-9378(11)91699-8)

Shynlova O, Tsui P, Jaffer S \& Lye SJ 2009 Integration of endocrine and mechanical signals in the regulation of myometrial functions during pregnancy and labour. European Journal of Obstetrics, Gynecology, and Reproductive Biology 144 (Suppl 1) S2-S10. (doi:10.1016/j.ejogrb.2009. 02.044)

Söhl G \& Willecke K 2003 An update on connexin genes and their nomenclature in mouse and man. Cell Communication \& Adhesion 10 173-180.

Solan JL \& Lampe PD 2014 Specific Cx43 phosphorylation events regulate gap junction turnover in vivo. FEBS Letter 588 1423-1429. (doi:10.1016/ j.febslet.2014.01.049)

Stewart MK, Gong X-Q, Barr KJ, Bai D, Fishman GI \& Laird DW 2013 The severity of mammary gland developmental defects is linked to the overall functional status of $\mathrm{C} \times 43$ as revealed by genetically modified mice. Biochemical Journal 449 401-413. (doi:10.1042/BJ20121070)

Stewart MK, Plante I, Bechberger JF, Naus CC \& Laird DW 2014 Mammary gland specific knockdown of the physiological surge in Cx26 during lactation retains normal mammary gland development and function. PLoS ONE 9 e101546. (doi:10.1371/journal.pone.0101546)

Stewart MKG, Simek J \& Laird DW 2015 Insights into the role of connexins in mammary gland morphogenesis and function. Reproduction 149 R279-R290. (doi:10.1530/REP-14-0661)

Tabb T, Thilander G, Grover A, Hertzberg E \& Garfield R 1992 An immunochemical and immunocytologic study of the increase in myometrial gap junctions (and connexin 43) in rats and humans during pregnancy. American Journal of Obstetrics and Gynecology 167 559-567. (doi:10.1016/S0002-9378(11)91453-7)

Taggart MJ, Europe-Finner GN \& Mitchell BF 2008 Possible dual role for prostacyclin in human pregnancy and labor. Journal of Clinical Investigation 118 3829-3832.

Tan H, Yi L, Rote NS, Hurd WW \& Mesiano S 2012 Progesterone receptor-A and $-B$ have opposite effects on proinflammatory gene expression in human myometrial cells: implications for progesterone actions in human pregnancy and parturition. Journal of Clinical Endocrinology and Metabolism 97 E719-E730. (doi:10.1210/jc.2011-3251)

Teleki I, Szasz AM, Maros ME, Gyorffy B, Kulka J, Meggyeshazi N, Kiszner G, Balla P, Samu A \& Krenacs T 2014 Correlations of differentially expressed gap junction connexins Cx26, Cx30, Cx32, Cx43 and Cx46 with breast cancer progression and prognosis. PLOS ONE 9 e112541. (doi:10.1371/journal.pone.0112541)

Teubner B, Michel V, Pesch J, Lautermann J, Cohen-Salmon M, Söhl G, Jahnke K, Winterhager E, Herberhold C, Hardelin J-P et al. 2003 Connexin30 (Gjb6)-deficiency causes severe hearing impairment and lack of endocochlear potential. Human Molecular Genetics 12 13-21. (doi:10.1093/hmg/ddg001)

Tong D, Lu X, Wang H-X, Plante I, Lui E, Laird DW, Bai D \& Kidder GM 2009 A dominant loss-of-function Gja1 (Cx43) mutant impairs parturition in the mouse. Biology of Reproduction 80 1099-1106. (doi:10.1095/biolreprod.108.071969)

Tudehope D, Vento M, Bhutta Z \& Pachi P 2013 Nutritional requirements and feeding recommendations for small for gestational age infants. Journal of Pediatrics 162 S81-S89. (doi:10.1016/j.jpeds.2012.11.057)

Winterhager E \& Kidder GM 2015 Gap junction connexins in female reproductive organs: implications for women's reproductive health. Human Reproduction Update 21 340-352. (doi:10.1093/humupd/ dmv007)

Winterhager E, Pielensticker N, Freyer J, Ghanem A, Schrickel JW, Kim J-S, Behr R, Grümmer R, Maass K, Urschel S et al. 2007 Replacement of connexin43 by connexin26 in transgenic mice leads to dysfunctional reproductive organs and slowed ventricular conduction in the heart. BMC Developmental Biology 7 26-40. (doi:10.1186/1471-213X-7-26)

Winterhager E, Gellhaus A, Blois SM, Hill LA, Barr KJ \& Kidder GM 2013 Decidual angiogenesis and placental orientation are altered in mice heterozygous for a dominant loss-of-function Gja1 (connexin43) mutation. Biology of Reproduction 89 111-123. (doi:10.1095/biolreprod.113.111690)

Xie N, Liu L, Li Y, Yu C, Lam S, Shynlova O, Gleave M, Challis JR, Lye S \& Dong X 2012 Expression and function of myometrial PSF suggest a role in progesterone withdrawal and the initiation of labor. Molecular Endocrinology 26 1370-1379. (doi:10.1210/me.2012-1088)

Xu C, Long A, Fang X, Wood SL, Slater DM, Ni X \& Olson DM 2013 Effects of PGF $2 \alpha$ on the expression of uterine activation proteins in pregnant human myometrial cells from upper and lower segment. Journal of Clinical Endocrinology and Metabolism 98 2975-2983. (doi:10.1210/jc. 2012-2829)

Yeager M \& Harris AL 2007 Gap junction channel structure in the early 21st century: facts and fantasies. Current Opinion in Cell Biology 19 521-528. (doi:10.1016/j.ceb.2007.09.001)

Young RC, Schumann R \& Zhang P 2002 The signaling mechanisms of long distance intercellular calcium waves (far waves) in cultured human uterine myocytes. Journal of Muscle Research and Cell Motility 23 279-284. (doi:10.1023/A:1022052910585)

Zakar T \& Mesiano S 2011 How does progesterone relax the uterus in pregnancy. New England Journal of Medicine 36 4972-4973.

Received 25 March 2015

First decision 13 May 2015

Revised manuscript received 7 June 2015

Accepted 6 July 2015 